Research Article

\title{
Physico-Chemical Characteristics and Level of Some Selected Metal in Edible Oils
}

\author{
Bereket Tesfaye and Alemayehu Abebaw \\ Department of Chemistry, College of Natural and Computational Science, Ambo University, 19 Ambo, Ethiopia
}

Correspondence should be addressed to Bereket Tesfaye; berekettesfaye20@yahoo.com

Received 18 March 2016; Accepted 9 June 2016

Academic Editor: Maria Roca

Copyright (C) 2016 B. Tesfaye and A. Abebaw. This is an open access article distributed under the Creative Commons Attribution License, which permits unrestricted use, distribution, and reproduction in any medium, provided the original work is properly cited.

\begin{abstract}
The physico-chemical properties and level of some essential metals of four edible oils, two imported (Viking and Avena) and two processed in Ethiopia (Selam and Nur) oil samples, were analyzed using classical wet chemical method and flame atomic absorption spectroscopy techniques, respectively. The result of physico-chemical properties shows that acid value in Avena and Viking oils which is $0.091 \pm 0.0042 \mathrm{mgKOH} / \mathrm{g}$ and $0.082 \pm 0.0047 \mathrm{mgKOH} / \mathrm{g}$, respectively, from palm oil variety and in Selam and Nur oils $0.276 \pm 0.0056 \mathrm{mgKOH} / \mathrm{g}$ and $0.188 \pm 0.0050 \mathrm{mgKOH} / \mathrm{g}$, respectively, from noug oil variety, saponification value in Avena and Viking oils which is $190.27 \pm 3.528 \mathrm{mgKOH} / \mathrm{g}$ and $189.80 \pm 3.528 \mathrm{mgKOH} / \mathrm{g}$, respectively, and in Selam and Nur oils $187.00 \pm 5.668 \mathrm{mgKOH} / \mathrm{g}$ and $143.05 \pm 8.527 \mathrm{mgKOH} / \mathrm{g}$, respectively, iodine value in Viking and Avena oils which is $97.545 \pm 0.6345 \mathrm{~g}$ and $53.807 \pm 1.0150 \mathrm{~g}$, respectively, and Nur and Selam oils $116.410 \pm 0.3863 \mathrm{~g}$ and $88.153 \pm 0.5300 \mathrm{~g}$, respectively, and peroxide value in Viking and Avena oils which is $1.413 \pm 0.0808 \mathrm{meq} / \mathrm{kg}$ and $1.233 \pm 0.0305 \mathrm{meq} / \mathrm{kg}$, respectively, from palm oil variety and in Selam and Nur oils $0.893 \pm 0.0503 \mathrm{meq} / \mathrm{kg}$ and $1.460 \pm 0.0600 \mathrm{meq} / \mathrm{kg}$, respectively, from noug oil variety were obtained. The level of essential metals in edible oil samples was analyzed after wet digestion. The results show that levels of $\mathrm{Cu}$ in Viking and Avena oils that were $0.62 \pm 0.022 \mathrm{mg}$ and $0.28 \pm 0.004 \mathrm{mg}$, respectively, and in Selam and Nur oils $0.86 \pm 0.003 \mathrm{mg}$ and $0.42 \pm 0.005 \mathrm{mg}$, respectively, and the levels of $\mathrm{Zn}$ in Viking and Avena oils that were $1.58 \pm 0.154 \mathrm{mg}$ and $1.27 \pm 0.255 \mathrm{mg}$, respectively, and in Selam and Nur oils $1.19 \pm 0.160 \mathrm{mg}$ and $1.47 \pm 0.567 \mathrm{mg}$, respectively, were obtained. The physico-chemical properties and level of essential metal revealed that four edible oils were acceptable to human consumption.
\end{abstract}

\section{Introduction}

Edible oils had made an important contribution to the diet of people in many countries serving as a good source of protein, lipid, and fatty acids for human nutrition including the repair of worn out tissues and new cells formation as well as a useful source of energy [1]. Vegetable oils and fats have wide application in foods where they are used in frying, salad dressing, shortening of pasty, margarine, cooking, and ice cream manufacture. In the world, vegetable oils and fat are found to be about $80-85 \%$ of edible oils and fat consumed by the public [2]. Edible oils are very important food for the world. The human body uses oils and fats in the diet for three purposes, such as being an energy source, being a structural component, and making powerful biological regulators. Oils and fats also play an important role in metabolic reactions in the human body [3].

Fats or oils consist of a wide group of compounds that are soluble in organic solvents and insoluble in water. They have lower densities than water and at normal room temperature range inconsistently from liquids to solids depending on their structure and composition. The words oils, fats, and lipids are all used to refer to fat; oils are usually used to refer to fats that are liquids at room temperature, while fats are usually used to refer to that are solid at normal temperature. Lipids are used to refer to both liquids and solids fats [4].

In quality control of edible oils, several parameters such as iodine value (degree of unsaturation), saponification value (average molecular weight), moisture content, and peroxide value as well as the free fatty acid content are of interest as 
they determine the quality and hence the economic value of the product. Currently, the majority of these parameters are determined by using classical wet chemical methods [5]. Edible oils have been analyzed for different metals using atomic absorption spectrometer (FAAS and GFAAS), inductively coupled plasma optical emission spectrometer (ICP$\mathrm{OES}$ ), and inductively coupled plasma mass spectrometer (ICP-MS). Atomic absorption spectroscopy (flame, graphite furnace, hydride generation, and cold vapour) is still the most widely used technique [6].

Palm oil (Elaeis guineensis) is a form of edible vegetable oil obtained from the mesocarp of the oil palm fruits. Previously, it was the second most widely produced vegetable oil after Soya bean oil; it may have now surpassed Soya bean oil as the most widely produced vegetable oil in the world today. Palm oil itself is reddish in color because it is rich in beta-carotene (a provitamin responsible for pigmentation of most fruits and vegetables and the precursor of vitamin $\mathrm{A}$, also an antioxidant, that destroys singlet oxygen and free radicals in the body) [6]. It is used as cooking oil and also in the processing of other foods. Red palm oil, besides providing calorie density to the diets, is also the largest natural source of tocotrienol and tocopherol (vitamin E family) [7].

Niger/nuog seed oil is obtained from the seeds of Niger plant, which belongs to Asteraceae family and to Guizotia genus. The botanical name of the plant is Guizotia abyssinica. Cultivation for the plant originated in the Ethiopian highlands and has since spread from Malawi to India. Niger seed yields about $30-35 \%$ of its weight in oil which is clear, slowdrying, and edible. Niger seed oil is polyunsaturated semidrying oil. It has pale yellow or orange color with a nutty taste and sweet odor. Raw oil has low acidity and can be used directly for cooking. Normally, it has a poor shelf life and will become rancid when stored for a long period. Its fatty acid composition is similar to sunflower oil and has high content of linoleic acid.

Several factors affect the edible oil quality such as agronomic techniques, seasonal conditions, sanitary state of drupes, ripening stage, harvesting and carriage systems, method and duration of storage, and processing technology. The major factors affecting edible oil quality are temperature, moisture, sunlight, soil fertility, and nutrients. It is possible to determine by different analytical techniques how to assess the quality of edible oil and to avoid possible adulterations [8].

The content of trace elements and their chemical forms can be naturally present in vegetable oils that were absorbed by the vegetable mainly from the soil where it was grown. A possibility of trace elements entry into edible oils other than the technological one is the environmental exposure to a large variety of elements. They can be also incorporated during the extraction and refining process to which the oil is submitted. Metals arrive in the plant via deposition as well as bioaccumulation from the soil via the natural metal sources and environmental pollution. In addition to these facts, the agricultural habits of the farmers play an important role in the metal contents of their products such as the application of fertilizers or metal containing plant protection agents. There are examples of zinc and copper that are potentially present in oil samples caused by environmental contamination [9].

\section{Material and Methods}

2.1. Equipment. Digital analytical balance (AA-200DS, Deriver Instrument Company, Germany) was used to weigh oil sample. KDN-20 digestive furnace (Kjeldahl method) and laboratory fume hood (Esco Frontier EBC-4A1) were used during sample digestion. Conical flasks, beakers, watch glass, and pipette were used in the measurement and preparation of sample and standard solutions. Volumetric flask of 25, 50,100 , and $250 \mathrm{~mL}$ were used to dilute sample solution and prepare standard solution. Flame photometer (ELICO SL 378, India) was used for determination of $\mathrm{Na}$ and $\mathrm{K}$. Double Beam Atomic Absorption Spectrophotometer (AA320N, China) was used for determination of $\mathrm{Fe}, \mathrm{Cu}$, and $\mathrm{Zn}$ content in edible oil.

2.2. Chemicals (Reagent). All reagents are of analytical grade unless otherwise stated. Deionized water was used for preparation and dilutions of standard solutions. Nitric acid $\left(\mathrm{HNO}_{3}\right)$ and sulfuric acid $\left(\mathrm{H}_{2} \mathrm{SO}_{4}\right)$ reagents were used for cleaning of glassware and for digestion of the samples. Representative edible oil samples were used for analysis. Chloroform, potassium iodide (KI), glacial acetic acid, and sodium thiosulphate were used for estimation of peroxide value. Hydrochloric acid $(\mathrm{HCl})$, sodium hydroxide $(\mathrm{NaOH})$, ethanol, and phenolphthalein indicators were used for estimation of acid value and saponification value, respectively; carbon tetra chloride, potassium iodide, and Hanus reagent were used for estimation of iodine value.

2.3. Sample Collection and Sampling. In the present investigation, two varieties of edible oil samples were selected. Currently, in Ethiopia, among different oil seed varieties, vastly processed edible oil has nuog seed oil, so it was selected for the study. Under this variety, two different oil samples such as Selam and Nur oils were nominated. These oils are branded and industrially processed. Presently, in Ethiopia, highly imported edible oil product has palm oil variety. So, it was selected for the study. Under this variety, two oil samples such as Viking and Avena oils were designated; they were also branded and industrially processed. Once the selection of representative oil samples was established, the oil samples were randomly purchased from different areas around Merkato commercial center. The purchased oil samples were packed in plastic bags and stored under room temperature in the laboratory until they were required for analysis.

2.4. Method for Determination of Acid Value. Three grams of each cooled oil sample was weighed in $250 \mathrm{~mL}$ of conical flasks and $30 \mathrm{~mL}$ of freshly neutralized ethyl alcohol (ethanol) was added to the samples and then shaken well to dissolve sample. The sample solution was boiled for about five minutes and cooled and then $1 \mathrm{~mL}$ of phenolphthalein indicator was added to the sample solution. The sample solution was treated with $1 \mathrm{~N}$ sodium hydroxide solution until permanent pink light color appeared. The acid value was estimated using the following equation:

$$
\text { Acid value }=\frac{2.82 \times V \times 100}{W \times 1000 \times 4},
$$


where $W$ is weight of oil that equals 3 grams, $V$ is titre value of $1 \mathrm{~N} \mathrm{NaOH}$, and 2.82 is equivalent weight of oleic acid [10].

2.5. Method for Determination of Saponification Value. Two grams of each oil sample was weighed in $250 \mathrm{~mL}$ Erlenmeyer flasks; then $25 \mathrm{~mL}$ of alcoholic potassium hydroxide solution was added into the flasks. The blank determination was conducted along with the sample. The samples flask and the blank flask were connected with air condensers and boiled gently in the water bath, steadily until the saponification was completed, indicated by absence of oily matter and the appearance of clear solution. Clarity was achieved in half hour boiling. After the flask and the condenser cooled, inside of the condensers was washed down with about $10 \mathrm{~mL}$ of ethanol and then $1 \mathrm{~mL}$ of phenolphthalein indicators was added to the solution. Excess potassium hydroxide was titrated with $0.5 \mathrm{~N}$ hydrochloric acid until cloudy solution was formed.

The saponification value was estimated using the following equation:

$$
\text { Saponification value }=\frac{56.1 \times(b-a) \times N}{W},
$$

where $W$ is weight of sample that equals 2 grams, $b$ is blank titre value, $a$ is sample titre value, and $N$ is 0.5 normality of $\mathrm{HCl}[11]$.

2.6. Method for Determination Iodine Value. Five grams of oil samples was weighed in $250 \mathrm{~mL}$ conical flasks and then $25 \mathrm{~mL}$ of carbon tetra chloride was added to each oil sample and content was mixed well. $25 \mathrm{~mL}$ of Hanus reagent was added to the solution, swirled for proper mixing, and kept in the flask in dark for half an hour. After standing, $15 \mathrm{~mL}$ of potassium iodide solution was added and then $100 \mathrm{~mL}$ of distilled water was added into the mixture and $1 \mathrm{~mL}$ starch indicator solution was added to the sample solution. Then, liberated iodine was titrated with $0.01 \mathrm{~N}$ of sodium thiosulphate solution; then, at the end, blue color was formed and then disappeared after thorough shaking. The blank determination was carried in the same manner as test sample but without oil. The iodine value was estimated using the following formula:

$$
\text { Iodine value }=\frac{(b-a) \times N \times 1.269 \times 100}{W},
$$

where $b$ is blank titre value, $a$ is sample titre value, $N$ is normality of thiosulphate, and $W$ is weight of sample [12].

2.7. Method for Determination of Peroxide Value. Five grams of each oil sample was weighed in $250 \mathrm{~mL}$ of conical flask; then, $30 \mathrm{~mL}$ of acetic acid and chloroform solvent mixture $(3: 2)$ was added to each oil sample and swirled to dissolve. Then, $1 \mathrm{~mL}$ of potassium iodide solution was added to the solution. The solution was kept for $1 \mathrm{~min}$ in dark room with occasional shaking and then $30 \mathrm{~mL}$ of distilled water was added. Slowly, titrate liberated iodine in $0.01 \mathrm{~N}$ sodium thiosulphate solution until vigorously shaking yellow color was gone and after that $1 \mathrm{~mL}$ of starch solution indicator was added and we continued titration by vigorous shaking to release all $\mathrm{I}_{2}$ from $\mathrm{CH}_{3} \mathrm{Cl}$ layer until blue color disappeared.
The peroxide value was estimated using the following equation:

$$
\text { Peroxide value }=\frac{V \times N \times 100}{W},
$$

where $V$ is volume of sodium thiosulphate, $N$ is normality used for titre, and $W$ is weight of the sample [13].

2.8. Determination of Metals Using Wet Digestion Method. Triplicate of 1 gram of each oil sample was weighed in $50 \mathrm{~mL}$ conical flasks. $20 \mathrm{~mL}$ of a freshly prepared mixture of concentrated $\mathrm{HNO}_{3}-\mathrm{H}_{2} \mathrm{O}_{2}(2: 1, \mathrm{v} / \mathrm{v})$ and $3 \mathrm{~mL}$ of $\mathrm{H}_{2} \mathrm{SO}_{4}$ solution were added to each flask and kept for $10 \mathrm{~min}$ at room temperature. The sample solutions were heated on Kjeldahl (KDN-20) digestive furnace at $250^{\circ} \mathrm{C}$ until a clear solution was obtained. Then, the samples were evaporated and the semidried mass was dissolved in $5 \mathrm{~mL} 0.2 \mathrm{M} \mathrm{HNO}_{3}$, then filtered through Whatman number 42 filter paper, and made up to final volume of $50 \mathrm{~mL}$ in volumetric flasks with ultrapure water and metal contents were determined in the diluted solutions by flame atomic absorption spectroscopy [14].

2.8.1. Digestion Methods for Selected Metal Analysis. The classical wet digestion reagent $\mathrm{HNO}_{3}+\mathrm{H}_{2} \mathrm{SO}_{4}$ (the most important and most versatile of the so-called wet-oxidation mixtures) was investigated by Danger and Flandin in 1841 for the destruction of organic matter. The use of pure concentrated $\mathrm{HNO}_{3}$ in a closed system under elevated temperatures and pressure is well known since 1860. Kjeldahl digested organic biological material in 1883 by boiling concentrated $\mathrm{H}_{2} \mathrm{SO}_{4}$ in an open system. Hydrogen peroxide was introduced by Classen and Bauer in 1884, and $\mathrm{HClO}_{4}$ was used at elevated temperatures by Tcherbak in 1893. Relatively new is Van Slyke's mixture of $\mathrm{H}_{2} \mathrm{SO}_{4}+\mathrm{H}_{3} \mathrm{PO}_{4}+\mathrm{KIO}_{3}+\mathrm{K}_{2} \mathrm{Cr}_{2} \mathrm{O}_{7}$ in 1954 [15].

2.9. Laboratory Quality Control (QC). All the glassware and apparatus to be used through the entire analysis were first washed with tap water and detergent in order to keep the analyte from contamination. Next, they were soaked with deionized water and followed by rinsing with $0.5 \mathrm{~N} \mathrm{HNO}_{3}$. Then, they were soaked with deionized water and followed by rinsing with $0.5 \mathrm{~N} \mathrm{HNO}_{3}$, and, then, rinsed again with deionized water and a corresponding analyte solution to be analyzed based on its necessity [16].

2.9.1. Standard Preparation for Calibration. Stock standard solution containing $1000 \mathrm{mg} / \mathrm{L}$ in $2 \% \mathrm{HNO}_{3}$ of the metals $\mathrm{Zn}, \mathrm{Cu}, \mathrm{Fe}, \mathrm{K}$, and $\mathrm{Na}$ was prepared from atomic absorption spectroscopic standard solution. The stock solutions were then used for preparation of calibration standards and spiking standards in the analysis of the samples [16].

Working Curve. A series of five standard solutions of known concentrations was prepared for each analyte to be analyzed in order to obtain the calibration curve, normally a linear regression equation:

$$
y=a x+b
$$


TABLE 1: Results of physico-chemical characteristics of the selected edible oil samples.

\begin{tabular}{lccccc}
\hline Oil samples & $\begin{array}{c}\text { Acid value } \\
(\mathrm{mgKOH} / \mathrm{g})\end{array}$ & $\begin{array}{c}\text { Saponification } \\
\text { value } \\
(\mathrm{mgKOH} / \mathrm{g})\end{array}$ & $\begin{array}{c}\text { Iodine value } \\
(\mathrm{g} / 100 \mathrm{~g})\end{array}$ & $\begin{array}{c}\text { Peroxide value } \\
(\mathrm{meq} / 1000 \mathrm{~g})\end{array}$ & $\begin{array}{c}\text { Moisture } \\
\text { content }(\%)\end{array}$ \\
\hline Viking palm oil & $0.082 \pm 0.0047$ & $189.80 \pm 3.528$ & $97.545 \pm 0.6345$ & $1.413 \pm 0.0808$ & $0.163 \pm 0.0015$ \\
Avena palm oil & $0.091 \pm 0.0042$ & $190.27 \pm 3.528$ & $53.807 \pm 1.0150$ & $1.233 \pm 0.0305$ & $0.123 \pm 0.0046$ \\
Selam nuog oil & $0.276 \pm 0.0056$ & $187.00 \pm 5.668$ & $88.153 \pm 0.5300$ & $0.893 \pm 0.0503$ & $0.173 \pm 0.0015$ \\
Nur nuog oil & $0.188 \pm 0.0050$ & $143.05 \pm 8.527$ & $116.410 \pm 0.3863$ & $1.460 \pm 0.0600$ & $0.160 \pm 0.0010$ \\
\hline
\end{tabular}

where $y$ is the instrument response, $x$ is the concentration of the chemical, $a$ is the slope factor (the calibration sensitivity), and $b$ is the intercept (the instrument response when analyte is absent, $x=0)[16]$.

2.10. Statistical Analysis. The significance of variation within each concentration of analyzed parameter was determined by paired comparison ( $t$-test) between the mean. Means were followed by standard deviation throughout to indicate variation between measurements of the parameters. Microsoft Excel and Statistical Packages for Social Science version 16.0 were used for graphic illustration of edible oil parameters. The significance was set at 0.05 .

2.11. Method Detection Limit (MDL) and Instrument Detection Limit (IDL). The IDL is the concentration equivalent to the analyte signal which is equal to three times the standard deviation $(s)$ of a series of ten replicate measurements of the calibration blank signal at the same wavelength as the analyte to be investigated, that is, IDL $=3 s$ [17]. To determine the MDL, an analyte-free matrix (reagent water) will be spiked with the target analyte at a concentration that is three to five times the estimated IDL. MDLs will be established for all analytes. A minimum of seven replicate aliquots of the fortified reagent water will be taken and processed through the entire analytical method. From these measurements, a standard deviation $(s)$ is calculated and the MDL will be calculated according to the following formula [18]:

$$
\mathrm{MDL}=s \times t .
$$

\section{Results and Discussions}

3.1. Results of Physico-Chemical Parameters. Some of selected physico-chemical properties such as acid value, saponification value, iodine value, peroxide value, and moisture content of four (4) edible oil samples analyzed are presented in Table 1, reported in terms of mean plus standard deviation $(N=3)$.

3.1.1. Acid Value. Acid value determination is often used as a general indication of the condition and edibility of the oil. The permissible level of acid value for all edible oils should be below $0.6 \mathrm{mgKOH} / \mathrm{g}$ (measured in potassium hydroxide per gram) from FAO/WHO recommendation (AOCS Official Method Cd 8-53, 2003). From the analysis of acid value, the four edible oil samples were below the permissible limit. According to the analysis of comparison paired $t$-test at $95 \%$ confidence interval $(P<0.05)$, results of Viking and Avena oils are not statistically significantly different $(P=0.184)$ from each other and results of Selam and Nur oils are strongly significantly different $(P=0.00)$ from each other.

3.1.2. Saponification Value. The FAO/WHO recommended saponification value for palm oil variety is $190-209 \mathrm{mgKOH} / \mathrm{g}$ and for nuog oil variety is $187-195 \mathrm{mgKOH} / \mathrm{g}$. From the analysis, Avena and Viking oil from palm oil variety and Selam oil from nuog oil variety agreed with FAO/WHO recommended value, but Nur oil is below the recommended value. According to the analysis of comparison paired $t$-test at $95 \%$ confidence interval $(P<0.05)$, results of Viking and Avena oil are not statistically significantly different $(P=0.423)$ from each other and results of Selam and Nur oils are significantly different $(P=0.002)$ from each other. The highest saponification value indicates a high content of triacylglycerol, consistent with the high ester value, and also indicates that the oil has the potential to be used for cosmetic industry [1]. The observation suggests that Avena and Viking oil from the palm oil variety and Selam oil from the nuog oil variety have a potential for making soap and other cosmetics.

3.1.3. Iodine Value. FAO/WHO recommended iodine value for palm oil is 50-55/gram and for nuog oil variety $112-$ 129/gram. According to the analysis, within the oil samples, Viking oil exhibits higher iodine value $(97.545 \pm 0.6345 \mathrm{~g} /$ $100 \mathrm{~g})$ than Avena oil $(53.807 \pm 1.0150 \mathrm{~g} / 100 \mathrm{~g})$ from palm oil variety, but compared with $\mathrm{FAO} / \mathrm{WHO}$ recommended standard Avena oil was gratified. From the nuog oil variety, Nur oil has higher iodine value $(116.410 \pm 0.3863 \mathrm{~g} / 100 \mathrm{~g})$ than Selam oil $(88.153 \pm 0.5300 \mathrm{~g} / 100 \mathrm{~g})$ and also Nur oil has well satisfied the FAO/WHO recommended iodine value, but Selam oil is below from the recommended standards. Oils having high iodine number are polyunsaturated indicating the degree of unsaturation and are desired by oil processors, while a lower iodine number is indicative of lower quality [1]. From this observation, it is suggested that Viking oil from the palm oil variety and Nur oil from nuog oil variety are richer in unsaturated fatty acids. The lower iodine value of Selam oil from nuog oil variety may have contributed to its greater oxidative storage stability. According to the analysis of comparison paired $t$-test at 95\% confidence interval $(P<$ 0.05), results of Viking and Avena oil are strongly significantly different $(P=0.00)$ from each other and also results of Selam and Nur oil are strongly significantly different $(P=0.00)$ from each other. 
TABLE 2: Flame atomic absorption spectroscopy working parameter or conditions for the selected metals.

\begin{tabular}{lccccc}
\hline Metal & Wave length $(\mathrm{nm})$ & Slit width $(\mathrm{nm})$ & Lamp current $(\mathrm{mA})$ & Air $(\mathrm{L} / \mathrm{min})$ & Acetylene $(\mathrm{L} / \mathrm{min})$ \\
\hline $\mathrm{Cu}$ & 324.8 & 0.4 & 5.0 & 1.0 & 3.0 \\
$\mathrm{Zn}$ & 213.9 & 0.7 & 5.0 & 1.0 & 3.0 \\
$\mathrm{Fe}$ & 248.3 & 0.2 & 6.0 & 1.0 & 3.0 \\
\hline
\end{tabular}

TABLE 3: Instrument calibration standard solution and their correlation coefficients.

\begin{tabular}{lcccc}
\hline Metals & Stock solution $(\mathrm{mg} / \mathrm{L})$ & Intermediates solution $(\mathrm{mg} / \mathrm{L})$ & Calibration solution $(\mathrm{mg} / \mathrm{L})$ & Correlation coefficient $\left(r^{2}\right)$ \\
\hline $\mathrm{Na}$ & 1000 & 100 & $1,2,4,8,16$ & 0.9999 \\
$\mathrm{~K}$ & 1000 & 100 & $1,2,4,8,16$ & 0.9977 \\
$\mathrm{Cu}$ & 1000 & 100 & $0.5,1,2,4,8$ & 0.9989 \\
$\mathrm{Zn}$ & 1000 & 100 & $0.5,1,2,4,8$ & 0.9999 \\
$\mathrm{Fe}$ & 1000 & 100 & $1,2,4,8,16$ & 0.9998 \\
\hline
\end{tabular}

3.1.4. Peroxide Value. FAO/WHO recommended peroxide values for palm and nuog oils were $\leq 10 \mathrm{meq} / 1000 \mathrm{~g}$. In the present study, the analyzed peroxide value in four edible oil samples was in agreement with $\mathrm{FAO} / \mathrm{WHO}$ recommended values. According to the analysis of comparison paired $t$-test at $95 \%$ confidence interval $(P<0.05)$, results of Viking and Avena oil were significantly different $(P=0.05)$ from each other and results of Selam and Nur oil were not significantly different $(P=0.09)$ from each other. The rate of peroxidation differed from one oil to another because it was related to different treatment to which the oils were subjected. In general, the peroxide value increased with storage time. Oils exposed to both atmospheric oxygen and light showed a much larger increase in peroxide value during storage [19].

\subsection{Analysis of Metals}

3.2.1. Instrument Working Conditions for Investigated Elements. Flame atomic absorption spectrometer equipped with air/acetylene flame with deuterium lamp background correction and hollow cathode lamp for individuals metals as radiation source was used for determination of $\mathrm{Zn}, \mathrm{Cu}$, and $\mathrm{Fe}$ and flame photometer was used for determination of $\mathrm{Na}$ and $\mathrm{K}$. The flame atomic absorption spectrometer (AAS) working parameters or conditions for the three elements are shown in Table 2.

(1) Instrument Calibration. The instrument was calibrated using a calibration blank and five series of respective working standards of each metal shown in the Table 3. The working standards of each metal were prepared from $100 \mathrm{mg} / \mathrm{L}$ intermediate standard solutions.

The correlation coefficients of the calibration curves of the metal standards were presented in Table 3 and were in the acceptable range (0.9977-0.999) for all metal analyses under the study. This shows that the linearity of the responses of individual element is sufficient to continue analysis.

3.3. Method Detection Limit (MDL) and Instrumental Detection Limit (IDL). Method detection limit, instrument detection limits, and limit of quantitation for each metal determined in the samples were tabulated in Table 4 . The analytical importance of these procedures was to confirm the performance of the method.

3.4. Level of Essential Metals in Edible Oils. The concentration of the selected essential metals in edible oil sample was determined by using flame photometer (FP) and flame atomic absorption spectroscopy (FAAS) techniques using the necessary calibration curves. The three replicate analyses were carried out for each sample.

In the present study, the levels of zinc, copper, iron, sodium, and potassium metals were found in each oil sample as shown in Table 5. According to the analysis, within the oil samples, Viking oil has high concentration of zinc metal $(1.58 \pm 0.154 \mathrm{mg})$ compared to Avena oil $(1.27 \pm 0.255 \mathrm{mg})$ from palm oil variety and from noug oil variety; Nur oil has recorded high concentration of zinc metal $(1.47 \pm 0.567 \mathrm{mg})$ compared to Selam oil $(1.19 \pm 0.160 \mathrm{mg})$. According to the analysis of comparison paired $t$-test at $95 \%$ confidence interval $(P<0.05)$, results of Viking and Avena oils were not significantly different statistically $(P=0.096)$ from each other and results of Selam and Nur oils were not strongly significantly different $(P=0.055)$ from each other. Viking oil has relatively high level of copper concentration $(0.62 \pm$ $0.221 \mathrm{mg})$ compared to Avena oil $(0.28 \pm 0.004 \mathrm{mg})$ from palm oil variety and from noug oil variety; Selam oil has high level of copper concentration $(0.86 \pm 0.003 \mathrm{mg})$ compared to Nur oil $(0.420 \pm 0.005 \mathrm{mg})$. According to the analysis of comparison paired $t$-test at 95\% confidence interval $(P<0.05)$, results of Viking and Avena oils were statistically significantly different from each other $(P=0.001)$ and results of Selam and Nur oils were strongly significantly different from each other $(P=0.00)$. Avena oil exhibits high level of iron concentration $(6.51 \pm 0.193 \mathrm{mg})$ compared to Viking oil $(4.66 \pm 0.331 \mathrm{mg})$ from palm oil variety and from noug oil variety; Selam oil has high level of iron concentration $(7.32 \pm 0.530 \mathrm{mg})$ compared to Nur oil $(6.08 \pm 0.818 \mathrm{mg})$. According to the analysis of comparison paired $t$-test at $95 \%$ confidence interval $(P<$ 0.05), results of Viking and Avena oils were statistically significantly different $(P=0.002)$ from each other and also results of Selam and Nur oils were significantly different 
TABLE 4: Method detection and instrument detection limit for each metal analyzed in the sample.

\begin{tabular}{lccc}
\hline Metal & Method detection limit $(\mathrm{mg} / \mathrm{L})$ & Instrument detection limit $(\mathrm{mg} / \mathrm{L})$ & Limit of quantitation $(\mathrm{mg} / \mathrm{L})$ \\
\hline $\mathrm{Na}$ & 0.0306 & 0.0086 & 0.306 \\
$\mathrm{~K}$ & 0.0191 & 0.0067 & 0.191 \\
$\mathrm{Cu}$ & 0.0246 & 0.0094 & 0.246 \\
$\mathrm{Zn}$ & 0.0151 & 0.0073 & 0.033 \\
$\mathrm{Fe}$ & 0.0283 & 0.0023 & 0.075 \\
\hline
\end{tabular}

TABLE 5: Concentration of the selected essential metals in the analyzed edible oil samples.

\begin{tabular}{lcccc}
\hline Metal & $\begin{array}{c}\text { Viking oil } \\
\text { Mean } \pm \text { SD } \\
(\mathrm{mg} / \mathrm{L})\end{array}$ & $\begin{array}{c}\text { Avena oil } \\
\text { Mean } \pm \text { SD } \\
(\mathrm{mg} / \mathrm{L})\end{array}$ & $\begin{array}{c}\text { Selam oil } \\
\text { Mean } \pm \text { SD } \\
(\mathrm{mg} / \mathrm{L})\end{array}$ & $\begin{array}{c}\text { Nur oil } \\
\text { Mean } \pm \text { SD } \\
(\mathrm{mg} / \mathrm{L})\end{array}$ \\
\hline $\mathrm{Na}$ & $4.17 \pm 0.153$ & $4.10 \pm 0.100$ & $3.80 \pm 0.100$ & $4.13 \pm 0.153$ \\
$\mathrm{~K}$ & $8.43 \pm 0.153$ & $8.27 \pm 0.209$ & $8.10 \pm 0.200$ & $10.30 \pm 0.200$ \\
$\mathrm{Cu}$ & $0.62 \pm 0.022$ & $0.28 \pm 0.004$ & $0.86 \pm 0.003$ & $0.42 \pm 0.005$ \\
$\mathrm{Zn}$ & $1.58 \pm 0.154$ & $1.27 \pm 0.255$ & $1.19 \pm 0.160$ & $1.47 \pm 0.567$ \\
$\mathrm{Fe}$ & $4.66 \pm 0.331$ & $6.51 \pm 0.193$ & $7.32 \pm 0.530$ & $6.08 \pm 0.818$ \\
\hline
\end{tabular}

$(P=0.037)$ from each other. The level of sodium was relatively high in Viking oil $(4.17 \pm 0.153 \mathrm{mg})$ compared to Avena oil $(4.10 \pm 0.100 \mathrm{mg})$ from palm oil variety and high in Nur oil $(4.13 \pm 0.153 \mathrm{mg})$ compared to Selam oil $(3.80 \pm 0.100 \mathrm{mg})$ from noug seed oil variety, and the level of potassium was also relatively high in Viking oil $(8.43 \pm$ $0.153 \mathrm{mg})$ compared to Avena oil $(8.27 \pm 0.209 \mathrm{mg})$ and high in Nur oil (10.30 $\pm 0.200 \mathrm{mg})$ compared to Selam oil $(8.10 \pm$ $0.200 \mathrm{mg})$.

\section{Conclusions}

Results obtained for physico-chemical parameters are as follows: acid value in the analyzed edible oil samples is below the permissible limit according to FAO/WHO recommended index. These indicate the analyzed oil samples were in a good stability and the triacylglycerol has not been hydrolyzed. The saponification value of Viking, Avena, and Selam oils agreed with FAO/WHO recommendation standards, but, in the present investigation, Nur oil is below the recommended index. From these results, we conclude that Viking, Avena, and Selam oils have a potential for making soap and other cosmetics.

The results of iodine value for Viking oil, Avena oil, and Nur oil indicate the degree of unsaturation and these oils are in good storage stability. The peroxide value of all the analyzed edible oil samples was in good agreement with the FAO/WHO recommendation standards. This indicates that no long time storage and no evidence about the rancidity of the edible oil samples were identified.

The results obtained from the investigated essential metals in the analyzed edible oil samples, produced in Ethiopia and imported, were acceptable to human consumption at nutritional and toxic levels. The result suggested that no more significant difference was observed in the level of essential metals within the edible oil samples.

\section{Competing Interests}

The authors declare that there are no competing interests regarding the publication of this paper.

\section{Acknowledgments}

The authors are grateful to Ambo University, Ethiopia, for providing all kind of support and inspiration to carry out this thesis work.

\section{References}

[1] I. Bello, "Physico-chemical properties of some commercial groundnut oil products sold in sokoto metropolis, northwest Nigeria," 2011.

[2] V. W. K. Fupi and P. C. Mørk, "Mafura nut oil and meal: processing and purification," Journal of the American Oil Chemists' Society, vol. 59, no. 2, pp. 94-98, 1982.

[3] H. Khan, M. Fida, I. U. Mohammadzai, and M. Khan, "Estimation of residual nickel and some heavy metals in vanaspati ghee," Journal of the Chinese Chemical Society, vol. 54, no. 3, pp. 737741, 2007.

[4] M. Anthea, J. Hopkins, C. W. McLaughlin et al., Human Biology and Health, Prentice Hall, Englewood Cliffs, NJ, USA, 1993.

[5] D. Mendil, O. D. Uluözlü, M. Tuzen, and M. Soylak, "Investigation of the levels of some element in edible oil samples produced in Turkey by atomic absorption spectrometry," Journal of Hazardous Materials, vol. 165, pp. 724-728, 2009.

[6] M. Rose, M. Knaggs, L. Owen, and M. Baxter, "A review of analytical methods for lead, cadmium, mercury, arsenic and tin determination used in proficiency testing," Journal of Analytical Atomic Spectrometry, vol. 16, no. 9, pp. 1101-1106, 2001.

[7] E. Johannesen, "Palm fruit oil-much more than ordinary oil," Journal of Science in Africa Magazine, 2005.

[8] R. Manorama and C. Rukmini, "Nutritional evaluation of crude palm oil," The Oil Technologists' Association of India, vol. 22, pp. 83-87, 1991. 
[9] R. Shaik, Analytical tool for rapid analysis of edible oil [M.S. thesis], Aalborg University Esbjerg, 2008.

[10] ISI Hand book of food Analysis (part III) 1984 page 67/ IUPAC2.201 (1979) I.S, 548 (Part-1)-1964 method of sampling and test for oils and fats/ISO 66011996 Determination of acid value and acidity.

[11] A.O.A.C, Official Method 920.160-Saponfication Number of Oils and Fats/IUPAC 2.202 I.S.I Hand Book of Food Analysis (Part XIII 1984), A.O.A.C, 17th edition, 2000.

[12] A.O.A.C, Official Method 920.159-Iodine Absorption Number of Oils and Fats/I.S.I Hand Book of Food Analysis Part-III-1984, A.O.A.C, 17th edition, 2000.

[13] A.O.A.C, Official Method 965.33 Peroxide value in oils and fats/Pearson's composition and analysis of food, 17th edition, pp. 641, 2000.

[14] F. Camin, R. Larcher, M. Perini et al., "Characterisation of authentic Italian extra-virgin olive oils by stable isotope ratios of $\mathrm{C}, \mathrm{O}$ and $\mathrm{H}$ and mineral composition," Food Chemistry, vol. 118, no. 4, pp. 901-909, 2010.

[15] Z. Mester and R. Sturgeon, Sample Preparation for Trace Element Analysis: Comprehensive Analytical Chemistry, Elsevier Science, Amsterdam, The Netherlands, 2003.

[16] E. Weiner, Environmental Chemistry: A Practical Guide for Environmental Professionals, Taylor \& Francis Group, Boca Raton, Fla, USA, 2nd edition, 2007.

[17] USEPA Method 200.5, "Determination of trace elements in drinking water by axially viewed inductively coupled plasmaatomic emission spectrometry," Tech. Rep. EPA/600/R-06/115, 2003.

[18] O. Ogbonna, L. Jimoh, F. Awagu, and I. Bamishaiye, "Determination of some trace elements in water samples within Kano, Metropolis," Pelagia Research Library, vol. 2, no. 2, pp. 62-68, 2011.

[19] O. C. Othman and F. N. Ngassapa, "Physico-chemical characteristics of some imported edible vegetable oils and fat marketed in Dar es salaam, Tanzania," Tanzania Journals of Natural and Applied Science, vol. 1, no. 2, 2010. 

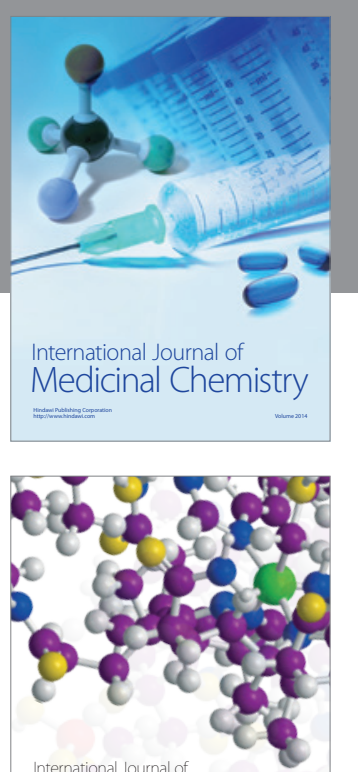

Carbohydrate Chemistry

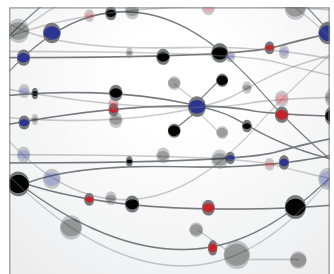

The Scientific World Journal
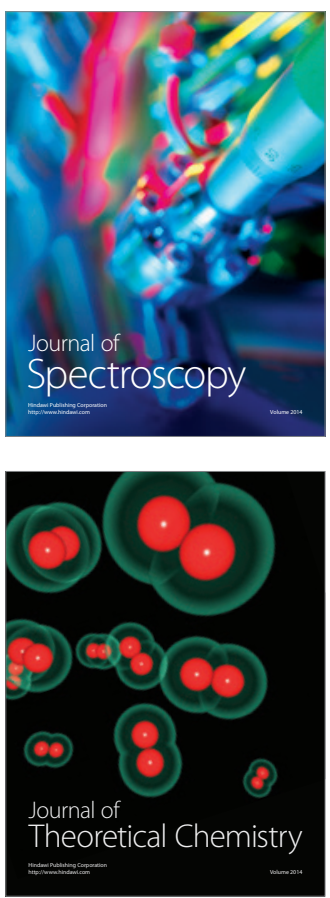
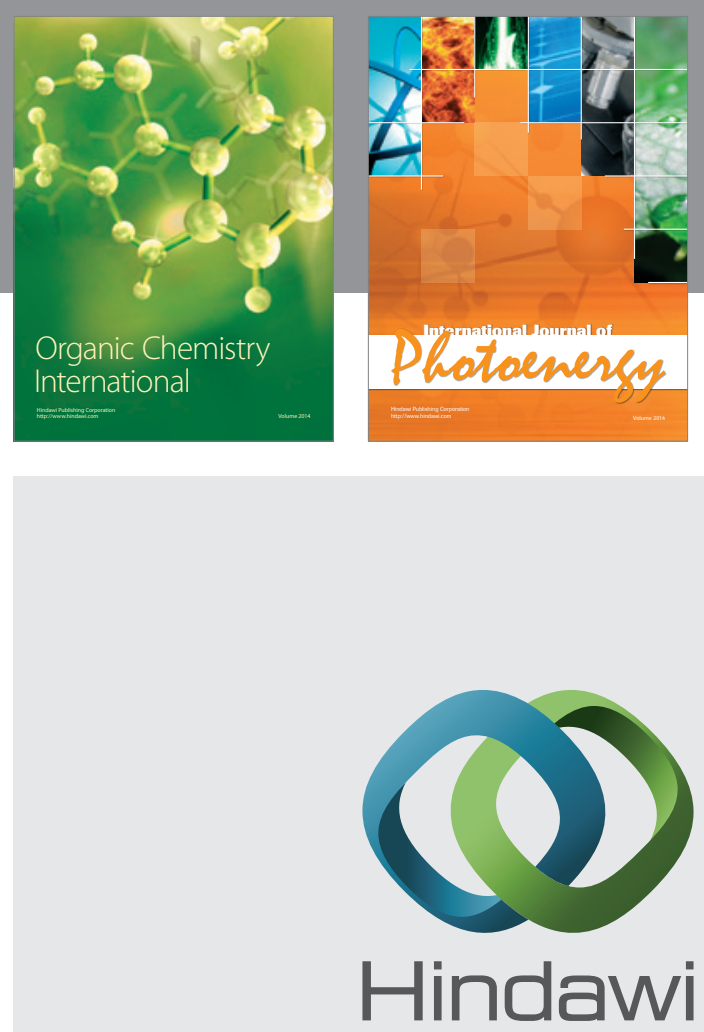

Submit your manuscripts at

http://www.hindawi.com

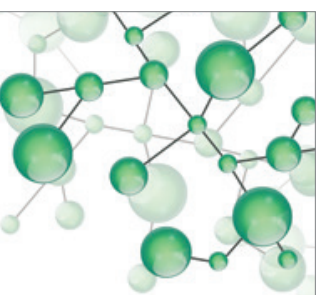

International Journal of

Inorganic Chemistry

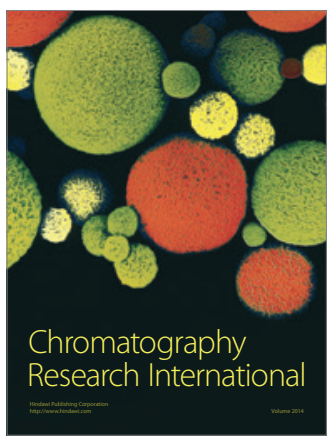

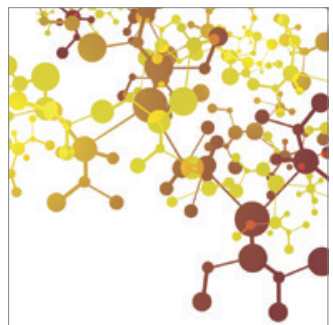

Applied Chemistry
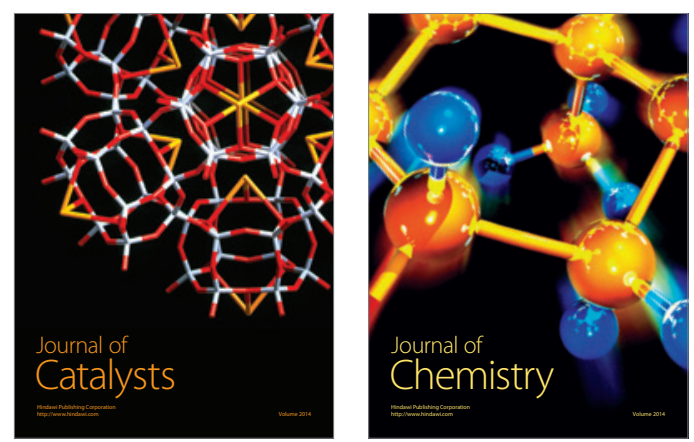
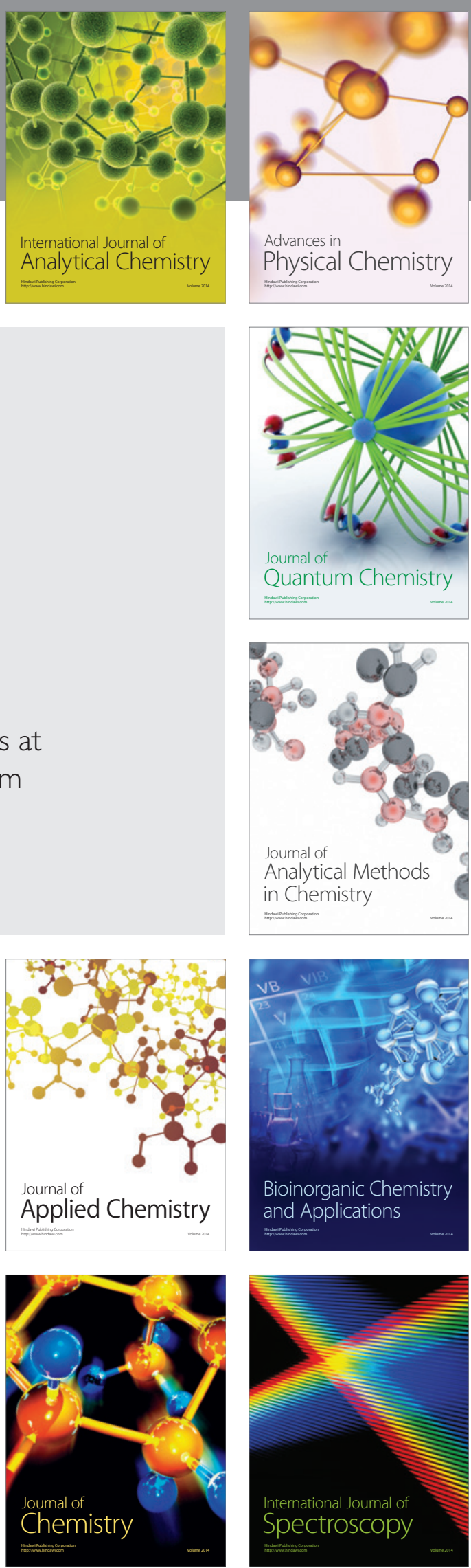